\title{
THE EFFECT OF EDUCATION WITH THE LEAFLET MEDIA ON MOTIVATION IN CARING BABY WITH DIARRHEA
}

\author{
Ferasinta $^{1}$, Endah Zulya Dinata ${ }^{2}$ \\ ${ }^{1}$ Program Studi Keperawatan UM Bengkulu, ${ }^{2}$ RSU UMMI Bengkulu
}

Email :

\begin{abstract}
Diarrhea is the highest cause of death in infants due to infectious disease characterized by increasing frequency of defecation more than three times per day with changes in the consistency of watery stool. The purpose of this study will to determine if health influence education with leaflet. The motivation of mother in caring for toddler diarrhea. The research is a quasyexperimental study with non randomized design without control group, pretest-posttest design with 27 taken then the respondents are divided group leaflet. Changes in motivation of the mother in caring toddler with diarrhea measured using questionnaires motivation with likert scale. There are difference of motivation of mother in caring for children with diarrhea before and after being given education with value $\rho$ value $<0.05$. Change in leaflet (motivation: 9.8, attitude: 10.2). It is expected that educators to apply audiovisual media in health education activities.
\end{abstract}

\section{Keywords: diarrhea, leaflets, motivation of mother, toddler}

\section{PENDAHULUAN}

Diare adalah pengeluaran feses yang tidak normal dan cair.Bisa juga didefinisikan sebagai buang air besar yang tidak normal dan berbentuk cair dengan frekuensi lebih banyak dari biasanya. Bayi dikatakan diare bila sudah lebih dari 3 kali buang air besar, sedangkan neonatus diare bila sudah lebih 4 kali buang air besar (Nanny, 2013). Data dari World Health Organization (WHO) tahun 2015 menunjukkan 8.790.000 anak dibawah usia 5 tahun meninggal diseluruh dunia dan $15 \%$ atau 1,5 juta dari kematian tersebut disebabkan oleh diare. Sebuah proporsi yang signifikan padahal penyakit diare dapat dicegah melalui air minum yang aman dan sanitasi yang bersih serta memadai (WHO, 2015).

Insiden diare pdi Indonesia pada balita masih cukup tinggi yaitu $(6,7 \%)$ tahun 2015. Lima provinsi tertinggi yang memiliki insiden diare pada balita adalah 
Aceh (10,2\%), Papua (9,6\%), DKI Jakarta (8,9\%), Sulawesi Selatan $(8,1 \%)$ dan Banten (8,0\%). Karakteristik diare balita terjadi pada kelompok umur 12-23 bulan (7,6\%), laki-laki (5,5\%), tinggal di pedesaan (5,3\%) (Kemenkes RI, 2013). Data statistik dari data rekam medik di Rumah Sakit Umum Daerah (RSUD) Tangerang, jumlah klien balita dengan diare mengalami peningkatan setiap tahunnya. Pada tahun 2014 sebanyak 195 penderita diare pada balita, tahun 2015 mengalami peningkatan sebanyak 261 kasus dan pada tahun 2016 sebanyak 343 kasus balita dengan diare, dari bulan Januari-Februari 2017 sebanyak 31 balita.

Perawat mempunyai peran yang penting dalam memberikan pemahaman tentang penyakit kepada anak dan orangtua. Proses pemberian informasi ini dapat dilakukan dengan memberikan pendidikan kesehatan yang menjadi bagian penting dalam intervensi keperawatan (Perry \& Potter, 2010). Tujuan pendidikan kesehatan adalah terjadinya perubahan sikap dan tingkah laku sehingga mampu berperan aktif dalam upaya mewujudkan derajat kesehatan yang optimal (Nursalam, 2013).Tujuan ini sejalan dengan teori model keperawatan health promotion model (HPM) yang dikembangkan oleh Nola J. Pender, dengan prinsip nilai harapan (Expectancy value) serta teori kognitif sosial (social cognitif theory). Promosi kesehatan berupa edukasi kesehatan pada klien dan keluarga merupakan tindakan positif yang mengarahkan pada perubahan perilaku (Alligood, 2014).

Berdasarkan studi pendahuluan yang dilakukan peneliti diruang rawat anak Rumah Sakit Umum Daerah Tangerang terhadap 4 Ibu dengan balita diare, pendidikan kesehatan pada Ibu tentang diare diberikan oleh perawat dengan menggunakan media leaflet. Selain itu, Ibu-ibu juga mendapatkan informasi tentang diare dari membaca artikel di internet. 2 dari Ibu yang mendapatkan edukasi dengan media leaflet mengungkapkan bahwa mereka mendapatkan motivasi untuk merawat anaknya.

Pemberian informasi berupa edukasi pada Ibu memiliki peran positif terhadap kemauan dan sikap Ibu dalam merawat anak balita yang sakit, hal ini membuat 
peneliti tertarik untuk meneliti bagaimana "pengaruh pemberian edukasi dengan media leaflet erhadap motivasi Ibu dalam merawat balita dengan diare".

\section{METODE}

Penelitian ini merupakan penelitian kuantitatif dengan desain penelitian "Quasi Experimental pre-post test". Penelitian “Quasi Experimental”. Populasi yang digunakan dalam penelitian ini adalah semua Ibu yang memiliki balita dengan diare yang sedang menjalani perawatan. Pemilihan sampel berdasarkan kriteria inklusi adalah karakteristik umum subyek penelitian dari suatu populasi target dan terjangkau yang akan diteliti (Nursalam, 2008) adalah sebagai berikut:

1. Ibu yang mempunyai balita Umur 1-5 tahun terdiagnosa diare yang dirawat di RSU Tangerang.

2. Ibu balita bersedia menjadi responden penelitian.

3. Ibu mampu membaca, menulis dan berkomunikasi.

4. Ibu balita yang tidak mengalami gangguan mental.

5. Ibu balita yang mengikuti proses penelitian sampai selesai

\section{HASIL}

Hasil penelitian tentang pengaruh pemberian edukasi dengan menggunakan media leaflet terhadap motivasi ibu dalam merawat balita dengan diare. Berdasarkan data yang diperoleh selama 4 minggu penelitian dan pengumpulan data, didapatkan sejumlah 9 responden yang memenuhi kriteria inklusi.

Tabel 1. Rata-Rata Karakteristik Responden Berdasarkan Usia Ibu (n=9)

\begin{tabular}{cccccc}
\hline Variabel & Mean & Median & SD & $\begin{array}{c}\text { Minimal- } \\
\text { Maksimal }\end{array}$ & $\mathbf{9 5 \%}$ CI \\
\hline Edukasi dengan Leaflet & 37.33 & 38.00 & 4.387 & $31-44$ & $33.96-40.71$ \\
\hline
\end{tabular}

Tabel 5.1 karakteristik responden Pada kelompok intervensi edukasi dengan media leaflet didapatkan rata-rata usia responden yaitu (37.33) dengan usia minimal yaitu 31 tahun dan usia maksimal 44 tahun dengan tingkat kemaknaan (33.96-40.71). 
Tabel 2. Distribusi Frekuensi Karakteristik Responden Berdasarkan Pendidikan dan Status Pekerjaan Ibu

\begin{tabular}{lccc}
\hline & Variabel & Leaflet \\
\cline { 3 - 4 } & & & $\mathbf{\%}$ \\
\hline Tingkat Pendidikan & & 8 & \\
1.Pendidikan Tinggi & & 1 & 88.9 \\
2. Pendidikan Rendah & Total & $\mathbf{9}$ & 11.1 \\
& & & $\mathbf{1 0 0}$ \\
Status Pekerjaan & & 2 & 22.2 \\
1. Bekerja & & 7 & 77.8 \\
2. Tidak Bekerja & Total & $\mathbf{9}$ & $\mathbf{1 0 0}$ \\
\hline
\end{tabular}

Tabel 2 menunjukkan karakteristik responden pada kelompok edukasi dengan leaflet sebagian besar responden berpendidikan tinggi yaitu 88.9\% (8 orang) dan sebagian besar tidak bekerja sebanyak 77.8\% (7 orang). Sedangkan pada kelompok edukasi dengan audiovisual dan leaflet sebagian besar berpendidikan tinggi yaitu $77.8 \%$ ( 7 orang) dan sebagian besar tidak bekerja sebanyak $77.8 \%$ (7 orang).

Tabel 3. Distribusi Frekuensi Motivasi IbuYang Diberikan Edukasi Dalam Merawat Balita dengan Diare

\begin{tabular}{|c|c|c|c|c|c|}
\hline \multicolumn{2}{|c|}{ Variabel } & \multicolumn{2}{|c|}{ Edukasi Leaflet } & \multicolumn{2}{|c|}{ Total } \\
\hline & & $\mathbf{N}$ & $\%$ & $\mathbf{N}$ & $\%$ \\
\hline \multirow{4}{*}{ Motivasi } & Sangat Tinggi & 8 & $88.9 \%$ & \multirow{4}{*}{27} & \multirow{4}{*}{$100 \%$} \\
\hline & Tinggi & 1 & $11.1 \%$ & & \\
\hline & Rendah & - & - & & \\
\hline & Sangat Rendah & - & - & & \\
\hline
\end{tabular}

Tabel 3 menunjukkan distribusi frekuensi kelompok edukasi dengan media leaflet sebagian besar responden yang memiliki motivasi sangat tinggi yaitu $88.9 \%$ ( 8 orang). 
Tabel 4. Perbedaan Rata-Rata Motivasi Ibu Sebelum dan Sesudah Diberikan Edukasi

\begin{tabular}{cccccc}
\hline \multirow{2}{*}{ Variabel } & Kelompok & Mean & SD & $\begin{array}{r}\text { Beda } \\
\text { Mean }\end{array}$ & P value \\
\hline \multirow{2}{*}{ Leaflet } & Sebelum & 64.00 & 3.873 & \multirow{2}{*}{8.3} & 0.000 \\
\cline { 2 - 5 } & Sesudah & 72.33 & 6.782 & & \\
\hline
\end{tabular}

Tabel 4 menunjukkan rata-rata nilai motivasi Ibu sebelum diberikan edukasi menggunakan leaflet yaitu (64.00) dengan standar deviasi (3.873), sedangkan motivasilbu sesudah diberikan edukasi leaflet diperoleh rata-rata nilai yaitu (72.33) dengan standar deviasi (6.782). Hasil analisis didapatkan ada perbedaan rata-rata nilai motivasi Ibu sebelum dan sesudah diberikan edukasi menggunakan leaflet yaitu (8.3), sehingga hasil uji statistik didapatkan nilai $\rho$ value $>0.05$. Maka dapat disimpulkan ada perbedaan yang signifikan antara motivasi Ibu sebelum dan sesudah diberikan edukasi menggunakan leaflet dengan keyakinan 95\%.

\section{PEMBAHASAN}

Berdasarkan hasil penelitian menunjukkan mayoritas responden pada kelompok edukasi dengan leaflet didapatkan rata-rata usia responden yaitu 37 tahun. Hasil penelitian ini sesuai dengan penelitian yang dilakukan oleh Wulandari (2014) yang menunjukkan usia Ibu antara (20-30) tidak berhubungan dengan kejadian diare pada balita dengan nilai $(\rho=0.08)$. Sejalan dengan penelitian terdahulu bahwa hasil uji statistik tidak dapat membuktikan adanya hubungan yang signifikan antara usia ibu dengan kejadian diare pada anak. Usia merupakan bagian penentu dari perilaku, namun usia bukanlah penentu utama. Usia seseorang belum dapat menjamin kemampuan dan kematangan dalam melakukan tindakan (Mahmudah, 2017).

Rata-rata tingkat pendidikan pada kelompok leaflet mayoritas responden berpendidikan tinggi. Responden dengan tingkat pendidikan tinggi akan lebih mengetahui penyakit diare melalui informasi yang didapat dan segera mencari cara menghentikan diare, segera mencari pelayanan kesehatan untuk mengetahui masalahnya sehingga lebih banyak terdeteksi dan terdiagnosis di Rumah Sakit. Tingkat pendidikan seseorang dapat mempengaruhi terhadap kemampuan 
kognitif. Kemampuan kognitif akan membentuk kemampuan berfikir seseorang, meliputi kemampuan memahami faktor-faktor yang berkaitan dengan sakit dan pengetahuan tentang sehat dan sakit serta praktek seseorang (Potter\&Perry, 2010). Pendidikan menjadi salah satu faktor predisposisi yang mempengaruhi perilaku seseorang terhadap kesehatan, seseorang yang berpendidikan tinggi akan mempunyai perilaku benar dalam mengatasi masalah. Pendidikan dapat mempengaruhi pengetahuan seseorang termasuk juga perilaku seseorang terhadap pola hidup terutama dalam memotivasi untuk sikap seseorang tersebut (Notoatmodjo, 2012).

Pendidikan memiliki peranan yang sangat penting dalam menentukan kualitas manusia, dengan pendidikan manusia memperoleh pengetahuan dan informasi. Semakin tinggi tingkat pendidikan seseorang maka akan semakin berkualitas hidupnya (Hurlock, 2010). Seseorang dengan pendidikan tinggi akan cenderung untuk mendapatkan dan menerima informasi, baik dari orang lain maupun dari media lebih mudah dan banyak, bukan berarti seseorang yang berpendidikan rendah pastilah berpengetahuan rendah pula, karena peningkatan pengetahuan seseorang tidak mutlak diperoleh di pendidikan formal tetapi dapat juga diperoleh dari sumber informasi lain seperti pemberian edukasi kesehatan (Notoatmodjo, 2012).

Penelitian ini sesuai dengan penelitian yang dilakukan Maryati (2009), yang menjelaskan tidak ada hubungan antara tingkat pendidikan Ibu dengan angka kejadian diare pada balita. Hasil penelitian lain yang sesuai dengan penelitian yaitu yang dilakukan oleh Indrawati dan Mulyani (2010) yang menyatakan bahwa tidak ada perbedaan signifikan antara kejadian diare dengan tingkat pendidikan Ibu. Sedangkan menurut Khalili (2010) menjelaskan pendidikan orang tua adalah faktor yang sangat penting dalam keberhasilan menajemen diare pada anak .orang tua dengan tingkat pendidikan rendah, khususnya buta huruf tidak akan dapat memberikan perawatan yang tepat pada anak diare karena kurang pengetahuan dan kurangnya kemampuan menerima informasi. 
Hasil penelitian yaitu ada pengaruh yang signifikan terhadap motivasi Ibu dalam merawat balita dengan diare sebelum dan sesudah diberikan edukasi leaflet. Leaflet adalah media yang berbentuk selembar kertas yang diberi gambar dan tulisan pada kedua belah sisi serta dapat dilipat sehingga praktis dan mudah dibawa, tetapi media ini hanya dapat diulang-ulang pemahamannya dan tidak memiliki efek gerak dan suara (Simamora, 2009). Hasil penelitian ini memperkuat penelitian Kawuriansari (2010) tentang Studi Efektivitas Leaflet terhadap skor pengetahuan remaja putri tentang dismenore di SMP Kristen 01 Purwokerto yang menunjukkan pengetahuan lebih baik setelah menerima leaflet. Hasil penelitian ini juga memperkuat penelitian Muslikha (2010) tentang peran leaflet terhadap pengetahuan Ibu tentang asi eksklusif dan motivasi untuk menyusui secara eksklusif yang menunjukkan bahwa leaflet memiliki peran.

Hasil penelitian Hidayati (2016) menunjukkan sikap responden baik pada masingmasing kelompok dan antara kelompok menunjukkan ada perbedaan yang signifikan setelah diberikan promosi kesehatan leaflet. Suatu sikap akan terbentuk ketika seseorang telah terpapar informasi berulang sehingga tercipta pemahaman dan kemudian akan terbentuk sikap (Fibriana, 2011).Sikap adalah suatu bentuk reaksi atau respon seseorang yang masih tertutup terhadap suatu stimulus atau objek dan sebuah bentuk evaluasi terhadap suatu aspek di sekitarnya maka pengalaman sebelumnya adalah faktor penentu perubahan sikap seseorang (Notoatmodjo, 2012).

\section{SIMPULAN DAN SARAN}

\section{SIMPULAN}

a. Karakteristik responden sebagian besar usia yaitu kelompok kelompok leaflet usia 37. Untuk pendidikan mayoritas responden berpendidikan tinggi, pada kelompok leaflet (88.9\%). Untuk status pekerjaan mayoritas responden tidak bekerja, kelompok leaflet (77.8\%).

b. Karakteristik motivasi Ibu mayoritas responden memiliki motivasi sangat tinggi, pada kelompok leaflet (88.9\%). 
c. Ada pengaruh yang signifikan terhadap motivasi Ibu dalam merawat balita dengan diare sebelum dan sesudah pemberian edukasi dengan media leaflet yaitu $\rho$ value motivasi (0.000).

\section{SARAN}

Saran yang diharapkan kepada perawat, tim medis dan tenaga kesehatan yang lain di rumah sakit untuk menggunakan media pendidikan kesehatan berupa media leaflet dalam kegiatan edukasi kesehatan untuk meningkatkan motivasi Ibu dalam merawat balita diare.

\section{DAFTAR RUJUKAN}

Ipora. (2010). Educating hispanic mothers management of infant gastroenteritis, utilizing mastery learning and overlearning in conjunction with audiovisual instructional methods. Jakarta.

Kapti, R., Rustina, Y., \& Widyatuti. (2013). Efektivitas audiovisual sebagai media penyuluhan kesehatan terhadap peningkatan pengetahuan dan sikap ibu dalam tatalaksana balita dengan diare di dua rumah sakit kota malang. Jakarta : jurnal Keperawatan Fakultas Ilmu Keperawatan Universitas Indonesia, 53-59.

Kawuriansari. (2010). Studi efektivitas leaflet terhadap skor pengetahuan remaja putri tentang dismenore di SMP Kristen 01 Purwokerto. Jurnal Ilmiah Kebidanan Vol 1 No 1 Hal 108-122.

Kemenkes RI. (2013). Riset kesehatan dasar : RISKESDAS 2013. Jakarta : Badan Penelitian dan Pengembangan Kesehatan Kementerian Kesehatan RI.

Muslikha. (2010).Peran leaflet terhadap pengetahuan ibu tentang asi eksklusif dan motivasi untuk menyusui secara eksklusif. Yogyakarta.

Muhammad. (2009). Penelitian pendidikan. Jakarta: Pustaka Aman.

Nanny Lia dewi, Vivian.(2013). Asuhan neonatus bayi dan anak balita.Jakarta : Salemba Medika.

Nursalam.(2013). Pendidikan dalam kesehatan.Jakarta : Salemba Medika.

Potter, P.A., Perry, A.G. (2010). Buku ajar fundamental keperawatan : konsep, proses, dan praktik. Jakarta : EGC.

Yurika.(2009). Pengaruh Pendidikan Kesehatan Terhadap Perubahan Pengetahuan Dan Sikap Dalam Pencegahan HIV/AIDS Pada Pekerja Seks Komersil. 